\title{
Functional Consequences of 5-HT Transporter Gene Disruption on 5-HT 1 Aeceptor-Mediated Regulation of Dorsal Raphe and Hippocampal Cell Activity
}

\author{
Clotilde Mannoury la Cour, ${ }^{1}$ Claudette Boni, ${ }^{1}$ Naïma Hanoun, ${ }^{1}$ Klaus-Peter Lesch, ${ }^{2}$ Michel Hamon, ${ }^{1}$ and \\ Laurence Lanfumey ${ }^{1}$ \\ 1/nstitut National de la Santé et de la Recherche Médicale U288, Neuropsychopharmacologie Moléculaire, Cellulaire et \\ Fonctionnelle, Faculté de Médecine Pitié-Salpêtrière, 75634 Paris Cedex 13, France, and 2Department of Psychiatry, \\ University of Würzburg, 97080 Würzburg, Germany
}

The consequences of the absence of $5-\mathrm{HT}$ reuptake on the functional properties of $5-\mathrm{HT}_{1 \mathrm{~A}}$ receptors were examined in the dorsal raphe nucleus and the hippocampus of knock-out mice lacking the serotonin transporter (5-HTT). Extracellular recordings showed that application of selective 5-HT reuptake inhibitors such as paroxetine and citalopram onto brainstem slices resulted in a concentration-dependent inhibition of 5-HT neuron firing in the dorsal raphe nucleus of wild-type 5-HTT+/+ mice, but not $5-\mathrm{HTT}-/-$ mutants. By contrast, the $5-\mathrm{HT}_{1 \mathrm{~A}}$ receptor agonists ipsapirone and 5-carboxamidotryptamine inhibited the discharge in both groups. However, the potency of these agonists was markedly decreased (by $\sim 55-$ and $\sim 6$ fold, respectively) in 5-HTT-/- compared with 5-HTT+/+ animals. Similarly, intracellular recordings showed that the potency of 5-carboxamidotryptamine to hyperpolarize 5-HT neurons in the dorsal raphe nucleus was significantly lower in $5-\mathrm{HTT}-1-$ than in $5-\mathrm{HTT}+/+$ animals. These data con- trasted with those obtained with hippocampal slices in which 5-carboxamidotryptamine was equipotent to hyperpolarize CA1 pyramidal neurons in both mutant and wild-type mice. As expected from their mediation through $5-\mathrm{HT}_{1 \mathrm{~A}}$ receptors, the effects of ipsapirone and 5-carboxamidotryptamine were competitively inhibited by the selective $5-\mathrm{HT}_{1 \mathrm{~A}}$ antagonist WAY 100635 in both groups. These data showed that 5-HTT gene knock-out induced a marked desensitization of $5-\mathrm{HT}_{1 \mathrm{~A}}$ autoreceptors in the dorsal raphe nucleus without altering postsynaptic 5- $\mathrm{HT}_{1 \mathrm{~A}}$ receptor functioning in the hippocampus. Similarities between these changes and those evoked by chronic treatment with 5-HT reuptake inhibitors emphasize the existence of regional differences in $5-\mathrm{HT}_{1 \mathrm{~A}}$ receptor regulatory mechanisms.

Key words: 5-HT transporter knock-out mice; 5-HT ${ }_{1 A}$ receptors; dorsal raphe nucleus; hippocampus; desensitization; in vitro electrophysiology
The involvement of the serotoninergic system in major psychiatric diseases, in particular mood disorders such as depression, is a well established clinical feature (Asberg et al., 1976; Cryan and Leonard, 2000). Accordingly, to date, the most frequently used antidepressants are the selective serotonin reuptake inhibitors (SSRIs), which act on the $\mathrm{Na}^{+} / \mathrm{Cl}^{-}$-dependent 5-HT transporter (5-HTT) (Graham et al., 1989; Lesch, 1997). In the CNS, 5-HTT seems to be essentially localized on serotoninergic neurons, at the level of somas, dendrites, axons, and terminals (Hensler et al., 1994; Sur et al., 1996; Tao-Cheng and Zhou, 1999), and only a minor glial expression of this protein has also been reported by some authors (Hirst et al., 1998; Pickel and Chan, 1999). In any case, it is well established that the 5-HTT is responsible for the primary mechanism of 5-HT inactivation in the CNS (Lesch, 1997; Masson et al., 1999).

Elucidation of the murine 5-HTT gene sequence (Chang et al.,

Received Aug. 7, 2000; revised Dec. 22, 2000; accepted Jan. 4, 2001.

This research was supported by the Institut National de la Santé et de la Recherche Médicale and Bristol-Myers Squibb Foundation (Unrestricted Biomedical Research Grant Program). C.M.C. was a recipient of a Fondation pour la Recherche Médicale fellowship during performance of this work. We are grateful to pharmaceutical companies (Lundbeck, Pierre Fabre, SmithKline Beecham, Troponwerke-Bayer, and Wyeth-Ayerst) for generous gifts of drugs.

Correspondence should be addressed to C. Mannoury la Cour, Institut National de la Santé et de la Recherche Médicale U 288, Neuropsychopharmacologie Moléculaire, Cellulaire et Fonctionnelle, Faculté de Médecine Pitié-Salpêtrière 91, Boulevard de l'Hôpital, 75634 Paris Cedex 13, France. E-mail: mannoury@idf.ext.jussieu.fr. Copyright (C) 2001 Society for Neuroscience $\quad 0270-6474 / 01 / 212178-08 \$ 15.00 / 0$
1996) allowed the generation of an animal model with targeted disruption of this gene by homologous recombination (Bengel et al., 1998). Indeed, the deletion of exon 2 results in an inactive gene and the complete absence of 5-HT reuptake activity in the homozygous 5-HTT-/- mice. No apparent developmental alterations were noted in the null mutant mice, suggesting that major compensatory mechanisms occur in these animals during embryonic and subsequent neurodevelopment (Bengel et al., 1998). However, marked depletions of 5-HT and of its metabolite 5-hydroxyindoleacetic acid in brain evidenced that adaptive changes in 5-HT neurotransmission do occur in 5-HTT-/- mutants (Bengel et al., 1998; Li et al., 1999; Fabre et al., 2000).

Previous studies using biochemical and neuroendocrinological approaches further investigated adaptive changes in 5-HT neurotransmission in 5 -HTT $-/-$ mutants with particular attention to 5-HT receptors. Indirect evidence of desensitization and downregulation of $5-\mathrm{HT}_{1 \mathrm{~A}}$ autoreceptors in the dorsal raphe nucleus (DRN) (Li et al., 1999; Fabre et al., 2000) and 5- $\mathrm{HT}_{2 \mathrm{~A}}$ receptors in the striatum and cerebral cortex (Rioux et al., 1999) has thus been reported in knock-out mice. Interestingly, similar changes in these receptors have previously been shown to occur after chronic blockade of 5-HT reuptake by SSRI (Chaput et al., 1986; SandersBush et al., 1989; Jolas et al., 1994; Kreiss and Lucki, 1995; Le Poul et al., 1995, 2000), thereby suggesting that the 5-HTT-/mutant mouse can be considered as a model of whole-life treatment with these drugs. Interestingly, Le Poul et al. (2000) recently 
reported that adaptive changes in $5-\mathrm{HT}_{1 \mathrm{~A}}$ receptors after chronic SSRI treatment in rats concerned $5-\mathrm{HT}_{1 \mathrm{~A}}$ autoreceptors in the DRN but not postsynaptic $5-\mathrm{HT}_{1 \mathrm{~A}}$ receptors in the hippocampus. These data led us to investigate further the functional status of $5-\mathrm{HT}_{1 \mathrm{~A}}$ receptors in these two areas in 5 -HTT-/- mutants versus wild-type mice. For this purpose, both extracellular and intracellular electrophysiological recordings of 5- $\mathrm{HT}_{1 \mathrm{~A}}$ expressing neurons in brain slices were used to quantitatively assess their responses to $5-\mathrm{HT}_{1 \mathrm{~A}}$ receptor stimulation.

\section{MATERIALS AND METHODS}

\section{Animals}

Experiments were performed using homozygous 5-HTT $-/-$, heterozygous 5-HTT $+/-$, and wild-type 5 -HTT $+/+$ littermates born from heterozygous mutants of C57BL6 genetic background. Genotyping was performed as described by Bengel et al. (1998). Animals were used at 2 months of age when their body weight in each genotype equally ranged between 20 and $25 \mathrm{gm}$. After weaning and sexing, males and females were housed separately in groups of six to eight animals per cage and maintained under standard laboratory conditions $\left(22 \pm 1^{\circ} \mathrm{C}\right.$; $60 \%$ relative humidity; $12 \mathrm{hr}$ light/dark cycle; food and water available ad libitum). In addition, some experiments were performed using CD1, C57BL6, and c129 control mice provided by the Centre d'Elevage R. Janvier (Le Genest-St. Isle, France) and IFFA Credo (Lyon, France), respectively.

Procedures involving animals and their care were conducted in conformity with the institutional guidelines that are in compliance with national and international laws and policies (council directive number 87-848, 19 October 1987, Ministère de l'Agriculture et de la Forêt, Service Vétérinaire de la Santé et de la Protection Animale, permissions \#0299 to M.H. and \#6269 to L.L.).

\section{Electrophysiology experiments}

Preparation of slices of DRN and dorsal hippocampus. Mice were decapitated, and the brains were rapidly removed and immersed in an ice-cold Krebs' solution, bubbled continuously with an $\mathrm{O}_{2}$ and $\mathrm{CO}_{2}$ mixture (95:5\%). A block of tissue containing the DRN or the dorsal hippocampus was cut into sections (350- to $400-\mu \mathrm{m}$-thick) in the same ice-cold Krebs' solution using a vibratome (Corradetti et al., 1998). Brainstem or hippocampus slices were then immediately incubated at room temperature $\left(20-23^{\circ} \mathrm{C}\right)$ for at least $1 \mathrm{hr}$ in an artificial CSF (ACSF) of the following composition (mM): $\mathrm{NaCl} 126, \mathrm{KCl} 3.5, \mathrm{NaH}_{2} \mathrm{PO}_{4} 1.2, \mathrm{MgCl}_{2}$ $1.3, \mathrm{CaCl}_{2} 2, \mathrm{NaHCO}_{3} 25$, D-glucose 11 , maintained at $\mathrm{pH} 7.3$ by continuous bubbling with $\mathrm{O}_{2}-\mathrm{CO}_{2}$ mixture. A slice of either the DRN or the CA1 hippocampal area was then placed on a nylon mesh, completely submerged in a small chamber, and superfused continuously with oxygenated $\mathrm{ACSF}\left(34^{\circ} \mathrm{C}\right)$ at a constant flow rate of $2-3 \mathrm{ml} / \mathrm{min}$ (Corradetti et al., 1998).

Extracellular recordings of serotoninergic neurons in the dorsal raphe nucleus. Extracellular recordings were made with glass microelectrodes filled with $2 \mathrm{M} \mathrm{NaCl}(10-15 \mathrm{M} \Omega)$. Cells were identified as 5-HT neurons according to the following criteria: biphasic action potentials and slow and regular pattern of discharge (1.5-2.5 spikes/sec) (Trulson and Frederickson, 1987; Jacobs and Azmitia, 1992). Firing was evoked in the otherwise silent neurons by adding the $\alpha_{1}$-adrenoceptor agonist phenylephrine $(3 \mu \mathrm{M})$ to the superfusing ACSF (VanderMaelen and Aghajanian, 1983). Baseline activity was recorded for 5-10 min before the application of drugs via a three-way tap system that allowed complete exchange of fluids within 2 min of arrival of a new solution. The electrical signals were fed into a high-input impedance amplifier (VF180; BioLogic, Claise, France), an oscilloscope, and an electronic ratemeter triggered by individual action potentials connected to an analog-todigital converter and a personal computer (Haj-Dahmane et al., 1991). The integrated firing rate was computed and recorded graphically as consecutive $10 \mathrm{sec}$ samples. The effect of a given drug was evaluated by comparing the mean discharge frequency during the 2 min before its addition to the superfusing ACSF with that recorded at the peak of the action of the drug, i.e., 3-10 min after starting the drug infusion. When an agonist was applied in the presence of an antagonist, the effect of the agonist was compared with the baseline firing rate and with the discharge frequency recorded during superfusion with the antagonist alone.

Intracellular recordings of serotoninergic neurons in the dorsal raphe nucleus and pyramidal neurons in the hippocampus. 5-HT neurons in the
DRN and pyramidal cells in the CA1 area of the hippocampus were recorded in current-clamp mode with $3 \mathrm{M} \mathrm{KCl-filled} \mathrm{electrodes} \mathrm{(50-80}$ $\mathrm{M} \Omega$ ), while brain slices were superfused with ACSF (Corradetti et al., 1998). Electrical signals were amplified with an Axoclamp 2A (Axon Instruments, Foster City, CA) and displayed on an oscilloscope and a chart recorder. Traces were stored in a digital tape recorder (DTR 1202; BioLogic; $48 \mathrm{kHz}$ sampling frequency) and a computer using pClamp6 software (3-10 kHz sampling frequency; Axon Instruments) for off-line measurements. Only neurons with stable resting membrane potential (range, -50 to $-90 \mathrm{mV})$ and input resistance $\left(R_{\mathrm{in}}\right.$; range, $40-140 \mathrm{M} \Omega$ for CA1 neurons and 100-500 M $\Omega$ for DRN cells) throughout the recording session were included in the analysis. Membrane potential in response to hyperpolarizing and depolarizing current pulses of 50/100 pA increments (range, -900 to $+500 \mathrm{pA}$ ) was measured before, during, and after tissue superfusion with drugs added to the ACSF. To draw concentrationresponse curves for the 5- $\mathrm{HT}_{1}$ agonist 5-carboxamidotryptamine (5-CT), the membrane potential was recorded while slices were superfused with increasing concentrations of this ligand. Preliminary experiments (data not shown) demonstrated that for a given cell, consecutive applications of increasing concentrations of 5-CT produced cumulative concentration-dependent responses with a maximal effect equal to that obtained with application of a single saturating concentration. Nonlinear regression fitting was performed using Prism 2.0 (GraphPad) software facilities for the determination of concentration-dependent hyperpolarization and decrease in $R_{\text {in }}$ caused by 5-CT.

\section{Statistical analyses}

All data are given as means \pm SEM. Extracellular and intracellular recording data were analyzed by one-way ANOVA and, in case of significance $(p<0.05)$, the $F$ test for significant treatment effects was followed by the two-tailed Student's $t$ test to compare the experimental groups with their controls. A value of $p<0.05$ was considered to be statistically significant.

\section{Chemicals}

The following drugs were used: ipsapirone (Bayer-Troponwerke, Cologne, Germany), 5-CT (Research Biochemicals, Natick, MA), paroxetine (SmithKline Beecham, Harlow, UK), citalopram (Lundbeck, Copenhagen, Denmark), and $N$-[2-[4-(2-methoxyphenyl)-1-piperazinyl]ethyl]- $N$ (2-pyridinyl)cyclohexane carboxamide (WAY 100635; Wyeth-Ayerst, Princeton, NJ).

\section{RESULTS}

In both the DRN and the hippocampus, electrophysiological recordings under the various pharmacological conditions tested did not reveal any significant differences between males and females of the homozygous 5-HTT-/-, heterozygous 5-HTT+/-, or wildtype phenotype. Accordingly, both males and females were used indifferently in the experiments reported herein.

\section{Extracellular recordings of DRN 5-HT neurons}

\section{Basal firing rate}

Because generation of the 5-HTT-/- knock-out model required the use of three different strains of mice (c129, CD1, and C57BL6) (Bengel et al., 1998), some heterogeneity in the genetic background might have still existed, thereby accounting for possible variations in the electrophysiological characteristics of DRN 5-HT neurons in 5-HT-/- mutants compared with wild-type animals of these strains. To directly assess this possibility, the spontaneous discharge frequency of DRN 5-HT neurons was compared in paired control 5-HTT+/+ mice and in c129, CD1, and C57BL6 mice. Indeed, the baseline firing rate of 5-HT neurons was similar in the four groups: c129, $1.72 \pm 0.19$ spikes/sec (mean $\pm \mathrm{SEM}, n=8$ ); CD1, $1.87 \pm 0.17$ spikes/sec $(n=7)$; C57BL6, $1.49 \pm 0.11$ spikes/ $\sec (n=12)$, and 5-HTT $+/+, 1.89 \pm 0.15$ spikes/sec $(n=12)$. Furthermore, the baseline firing rate of DRN 5-HT neurons was also not significantly different from these values in heterozygous 5-HTT $+/-, 1.88 \pm 0.19$ spikes/sec $(n=6)$ and homozygous 5 -HTT $-/-$ mutants, $1.66 \pm 0.18$ spikes/sec $(n=10)$. 
A

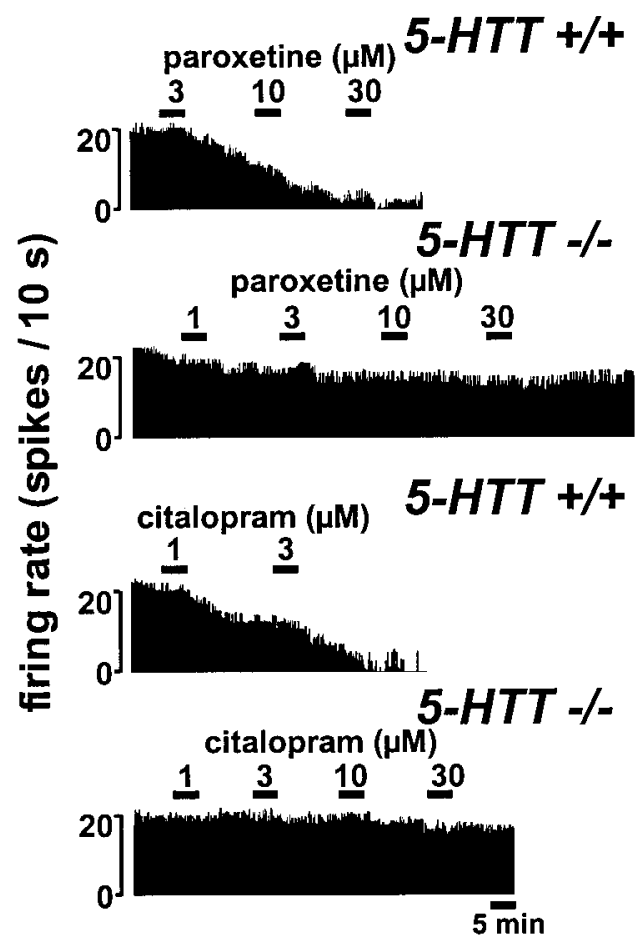

B

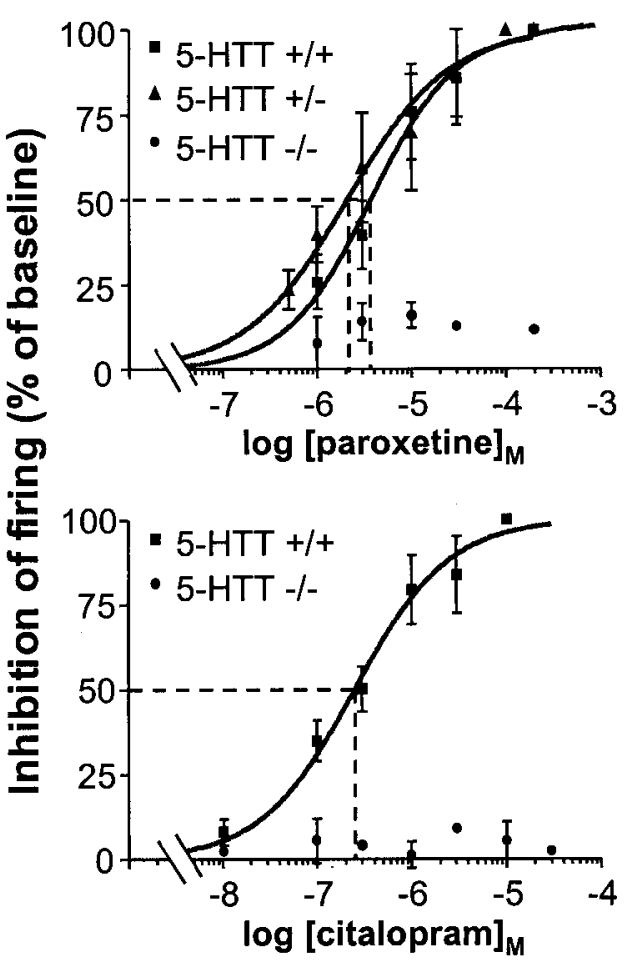

Figure 1. Effects of paroxetine and citalopram on the firing of 5-HT neurons in the DRN of 5-HTT knock-out and wild-type mice. $A$, Integrated firing rate histograms (in spikes per $10 \mathrm{sec}$ ) showing the effects of increasing concentrations of paroxetine (top) or citalopram (bottom) on the electrical activity of DRN 5-HT neurons in brainstem slices from 5 -HTT $-/-$ and 5 -HTT $+/+$ mice. $B$, Concentration-dependent inhibition by paroxetine (top) or citalopram (bottom) of the firing of DRN 5-HT neurons in $5-\mathrm{HTT}-1-$ and/or $5-\mathrm{HTT}+/-$ mutants compared with $5-\mathrm{HTT}+/+$ wildtype mice. Paroxetine- or citalopraminduced inhibition is expressed as a percentage of the baseline firing rate. Each point is the mean \pm SEM of data obtained from three to seven individual cells. The dotted lines illustrate the determination of $\mathrm{EC}_{50}$ values (abscissa).
Ipsapirone also inhibited the discharge of DRN 5-HT cells in the 5-HTT+/- and 5-HTT-/- mutants, but within higher concentration ranges than in wild-type animals. Although the increase in the $\mathrm{EC}_{50}$ value of ipsapirone in heterozygous $5-\mathrm{HTT}+/-$ mice $\left(\mathrm{EC}_{50}=115.3 \pm 7.3 \mathrm{nM} ; n=9\right)$ was not significant, that in homozygous 5 -HTT $-/-$ mutants $\left(\mathrm{EC}_{50}=\right.$ $3.5 \pm 1.1 \mu \mathrm{M} ; n=10)$ was highly significant $(p<0.001)$, indicating an $\sim 55$-fold decrease in the potency of the $5-\mathrm{HT}_{1 \mathrm{~A}}$ receptor agonist in the latter group compared with wild-type controls. In spite of these differences, complete blockade of the discharge of DRN 5-HT cells could be achieved in the three groups, but with different concentrations of ipsapirone $(1 \mu \mathrm{M}$ in $5-\mathrm{HTT}+/+$ and 5-HTT $+/-$ mice, $100 \mu \mathrm{M}$ in 5-HTT $-/-$ mice) (Fig. 2). Similar results were found with $5-\mathrm{CT}$ as $5-\mathrm{HT}_{1}$ agonist. Thus, 5-CT (1 nм to $10 \mu \mathrm{M})$ induced a concentration-dependent decrease in the firing rate of DRN 5-HT neurons with a significantly $(p<0.001)$ lower potency in knock-out $\left(\mathrm{EC}_{50}=52.7 \pm 3.6\right.$ $\mathrm{nM} ; n=10)$ than in wild-type mice $\left(\mathrm{EC}_{50}=9.05 \pm 1.26 \mathrm{nM} ; n=\right.$ 10). However, the relative decrease in 5-CT potency in the mutants (by approximately sixfold) was less than that noted for ipsapirone, as illustrated by the shift to the right of concentration-response curves, which was of much larger amplitude with the latter compared with the former agonist (Fig. 2). In any case, as expected from their mediation through $5-\mathrm{HT}_{1 \mathrm{~A}}$ autoreceptors, the inhibitory effects of both ipsapirone and 5-CT were prevented by the selective $5-\mathrm{HT}_{1 \mathrm{~A}}$ antagonist WAY 100635 (1-3 nM) in both wild-type and mutant mice (Fig. 2).

\section{Effects of 5-HT ${ }_{1 A}$ receptor blockade by WAY 100635}

Further characterization of ipsapirone-WAY 100635 interactions consisted of investigating the concentration-dependent inhibition of DRN 5-HT neuron firing by ipsapirone in the absence or the presence of a fixed concentration $(2 \mathrm{nM})$ of the $5-\mathrm{HT}_{1 \mathrm{~A}}$ receptor 


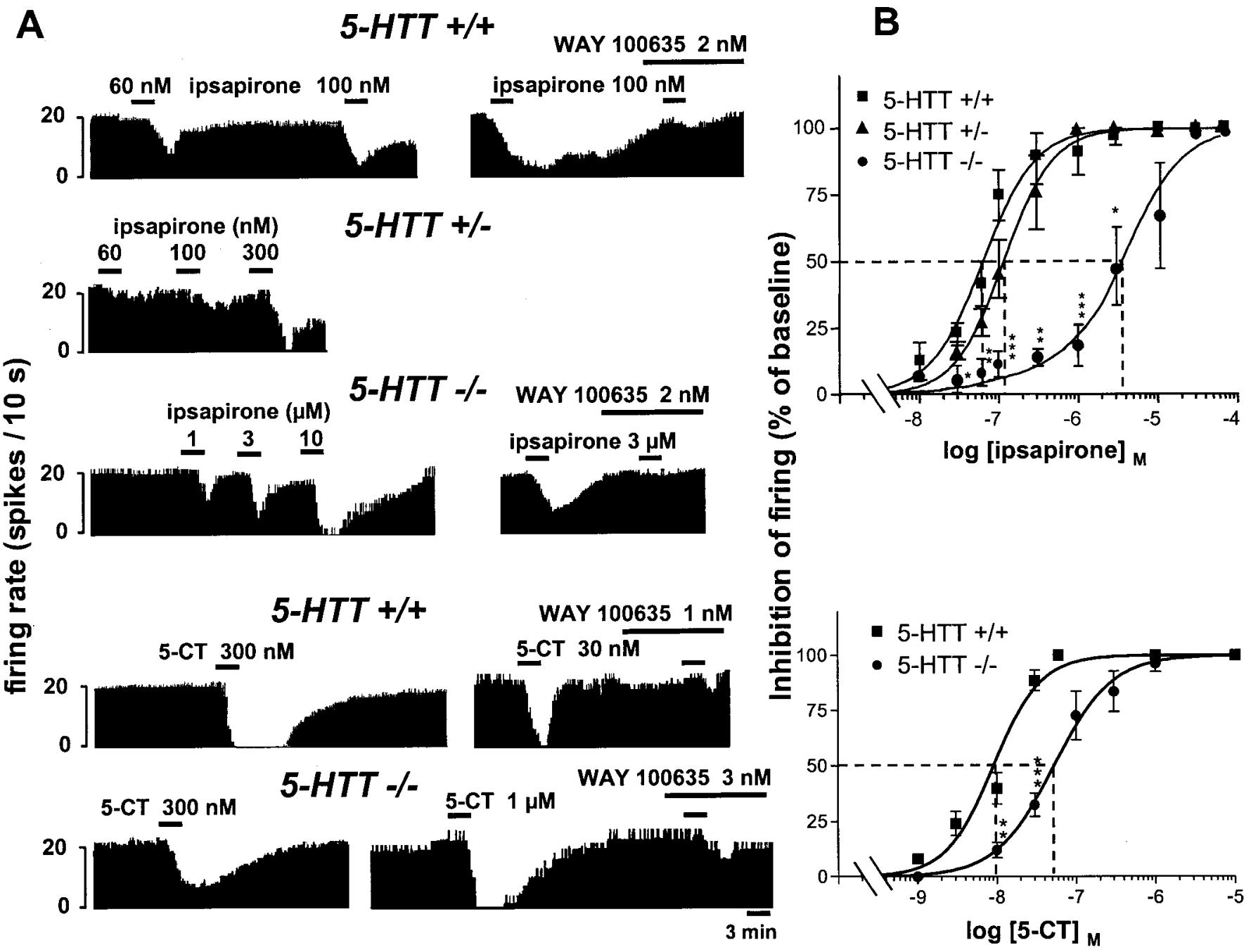

Figure 2. Concentration-dependent inhibition by ipsapirone or 5-CT of the electrical activity of DRN 5-HT neurons in 5-HTT knock-out and wild-type mice. Prevention by WAY 100635. A, Integrated firing rate histograms (in spikes per $10 \mathrm{sec}$ ) showing the inhibitory effect of ipsapirone and its prevention by WAY 100635, on the electrical activity of DRN 5-HT cells in 5-HTT $-/-$ and 5-HTT $+/-$ mutants compared with 5-HTT $+/+$ wild-type mice (top). The effect of 5-CT (bottom), and its prevention by WAY 100635, are illustrated in 5-HTT $+/+$ and 5-HTT-/- mice. Histograms are from different neurons. B, Concentration-dependent inhibition by ipsapirone (top) or 5-CT (bottom) of the firing of DRN 5-HT neurons in 5-HTT $+/+, 5-\mathrm{HTT}-/-$, and/or 5-HTT $+/-$ mice. Agonist-induced inhibition is expressed as a percentage of the baseline firing rate. Each point is the mean \pm SEM of data obtained from three to seven individual cells. The dotted lines illustrate the increase in the $\mathrm{EC}_{50}$ values (abscissa) of ipsapirone and 5-CT in 5-HTT-/- compared with 5-HTT $+/+$ mice. ${ }^{*} p<0.05 ;{ }^{* *} p<0.01 ;{ }^{* * *} p<0.001$ as compared with the corresponding inhibition in $5-\mathrm{HTT}+/+$ and $5-\mathrm{HTT}+/-$ mice.

antagonist. Data in Figure 3 show that WAY 100635 produced a shift to the right of the ipsapirone curve in wild-type as well as mutant mice, as expected from competitive inhibition of the effect of ipsapirone by WAY 100635. Calculation of the $\mathrm{IC}_{50}$ value of WAY 100635 from these curves yielded $0.065 \pm 0.015,0.078 \pm$ 0.021 , and $0.140 \pm 0.035 \mathrm{nM}$ (means $\pm \mathrm{SEM} ; n \geq 5$ for each value) in 5-HTT $+/+, 5-\mathrm{HTT}+/-$, and 5-HTT-/-mice, respectively.

In a second series of experiments, the concentration-dependent prevention by WAY 100635 (5 pM-5 nM) of the inhibitory effect of a fixed concentration of ipsapirone $(300 \mathrm{nM})$ on the discharge of DRN 5-HT neurons was compared in 5-HTT $+/+$ and 5 -HTT-/- mice. Calculations of the $\mathrm{IC}_{50}$ of the $5-\mathrm{HT}_{1 \mathrm{~A}}$ antagonist yielded values in the same range as those calculated from the previous series of experiments and did not significantly differ between wild-type $(0.093 \pm 0.032 \mathrm{nM} ; n=5)$ and knock-out $(0.045 \pm 0.014 \mathrm{nM} ; n=4)$ animals.

\section{Intracellular recordings of DRN 5-HT neurons and hippocampal pyramidal neurons}

DRN 5-HT neurons

In the absence of drugs, 5-HT cells recorded in 5-HTT $+/+(n=$ $6)$ as well as in null mutants $(n=5)$, exhibited similar membrane potential and $R_{\text {in }}$ ranging from -66 to $-83 \mathrm{mV}$ and 158 to 255 $\mathrm{M} \Omega$, respectively. Bath-applied ipsapirone evoked both a concentration-dependent membrane hyperpolarization (with a maximal response of $-4.50 \pm 0.76 \mathrm{mV}, n=4$, in the presence of $300 \mathrm{~nm}$ ipsapirone) and a decrease in $R_{\text {in }}$ (down to $62 \%$ of baseline value) of DRN 5-HT neurons in wild-type mice (Fig. $4 A$ ). By contrast, neither the membrane potential nor the $R_{\text {in }}$ of DRN 5-HT neurons in slices from 5-HTT-/- mutants were affected by ipsapirone, even at a concentration as high as $30 \mu \mathrm{M}$ (Fig. 4A). Different results were obtained with the other agonist tested, 5-CT, because this compound, in contrast to ipsapirone, 

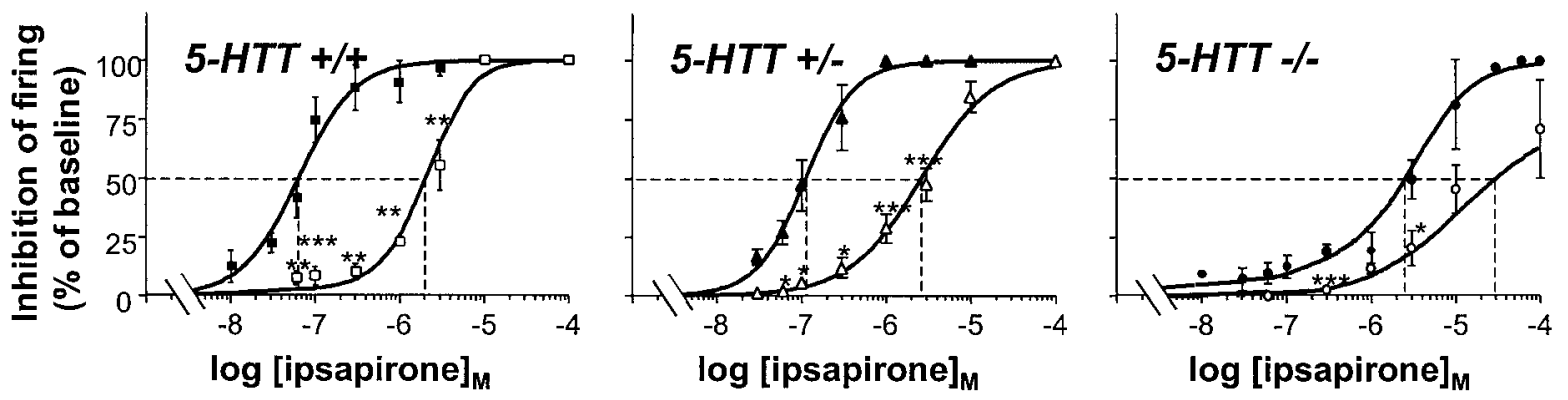

Figure 3. Competitive inhibition by WAY 100635 of the negative effect of ipsapirone on the firing of DRN 5-HT neurons in 5-HTT-/- and 5-HTT +/mutants compared with $5-\mathrm{HTT}+/+$ wild-type mice. Experiments were as described in the legend to Figure 2 except that the effects of various concentrations of ipsapirone were tested in the absence (black symbols) or the presence (open symbols) of 2 nM WAY 100635. Inhibition caused by ipsapirone is expressed as a percentage of baseline firing rate. Each point is the mean \pm SEM of data obtained from five to seven individual cells. ${ }^{*} p<$ $0.05 ; * p<0.01 ; * * * p<0.001$ as compared with corresponding data in the absence of WAY 100635.

produced a concentration-dependent membrane hyperpolarization of DRN 5-HT neurons in both knock-out and wild-type mice (Fig. 4B,C). As expected from the higher agonist efficacy of 5-CT compared with ipsapirone (Bockaert et al., 1987; Hoyer et al., 1994), maximal membrane hyperpolarization induced by the former agonist was $(\sim 2.5$-fold) larger than that observed with the latter in wild-type animals (Fig. 4C). Concentration-dependent curves showed no difference in 5-CT-induced maximal membrane hyperpolarization in 5 -HTT $-/-$ versus 5 -HTT $+/+$ mice; however, the potency of this agonist was significantly $(p<0.001)$ less in the mutants $\left(\mathrm{EC}_{50}=89.6 \pm 2.9 \mathrm{~nm} ; n=3\right)$ than in wild-type $\left(\mathrm{EC}_{50}=11.9 \pm 1.0 \mathrm{nM} ; n=3\right)$ animals (Fig. $\left.4 C\right)$ In both groups, the effects of 5-CT (300 nM) were completely prevented by WAY 100635 (10 nM), which, on its own, affected neither the membrane potential nor the $R_{\text {in }}$ of DRN 5-HT cells (Fig. $4 B$; data not shown).

\section{Hippocampal pyramidal neurons}

Like that noted for DRN 5-HT cells, no significant differences were found in the membrane potential (range, -53 to $-78 \mathrm{mV}$ ) and the $R_{\text {in }}$ value (range, 48-133 M 2 ) of CA1 pyramidal cells between 5-HTT-/- mutant and 5-HTT+/+ wild-type mice. The addition of increasing concentrations (30 nM to $1 \mu \mathrm{M}$ ) of 5-CT into the ACSF superfusing hippocampal slices from wild-type mice elicited a hyperpolarization of cell membrane (maximal response, $-6.55 \pm 0.41 \mathrm{mV}$ with $300 \mathrm{~nm} 5-\mathrm{CT} ; n=8)$ and a decrease in $R_{\text {in }}$ value $(-44.2 \%$ with $300 \mathrm{~nm} 5-\mathrm{CT}$ ) (Fig. $5 A, B)$. These effects were reversible with recovery of predrug values within $\sim 15 \mathrm{~min}$ after removal of 5 -CT from the superfusing ACSF (Fig. 5A). As illustrated in Figure 5B, 5-CT-induced effects were clearly concentration-dependent, with an $\mathrm{EC}_{50}$ value of $41.0 \pm 4.0 \mathrm{~nm}(n=6)$. Similar effects were noted on CA1 pyramidal cells in hippocampal slices from 5 -HTT $-/-$ animals, and indeed the maximal hyperpolarization $(-6.05 \pm 0.50 \mathrm{mV}$; $n=9)$ and decrease in $R_{\text {in }}(-43.7 \%)$ in response to 300 nм 5-CT (Fig. 5), and the potency of this drug $\left(\mathrm{EC}_{50}=51.1 \pm 5.0 \mathrm{nM} ; n=\right.$ 9) to trigger these effects, were not significantly different in the homozygous mutants compared with wild-type mice.

As expected from effects mediated through $5-\mathrm{HT}_{1 \mathrm{~A}}$ receptor stimulation, both the membrane hyperpolarization and the decrease in $R_{\text {in }}$ value caused by $300 \mathrm{~nm} 5$-CT could be completely prevented by bath application of $10 \mathrm{nM}$ of the selective $5-\mathrm{HT}_{1 \mathrm{~A}}$ receptor antagonist WAY 100635 (Fig. 5A). On its own, WAY 100635 affected neither the membrane potential nor the $R_{\text {in }}$ value of CA1 pyramidal neurons in homozygous mutant (Fig. $5 A$ ) as well as wild-type (data not shown) mice. Concentrationdependent prevention by WAY 100635 (0.3-10 nM) of the membrane hyperpolarization induced by $300 \mathrm{nM} 5-\mathrm{CT}$ showed no differences between wild-type $\left(\mathrm{IC}_{50}=0.96 \pm 0.04 \mathrm{nM} ; n=3\right)$ and knock-out $\left(\mathrm{IC}_{50}=1.07 \pm 0.06 \mathrm{~nm} ; n=3\right)$ mice (Fig. $\left.5 C\right)$.

\section{DISCUSSION}

The present study showed that the lack of 5-HT reuptake because of the deletion of exon 2 in the 5-HTT gene (Bengel et al., 1998) induces major alterations in central 5-HT neurotransmission. In particular, the somatodendritic $5-\mathrm{HT}_{1 \mathrm{~A}}$ autoreceptor, which exerts a key role in the modulation of 5-HT tone (Hamon, 1997), is deeply desensitized in the knock-out 5-HTT-/- mice. However, such a functional adaptation does not extend to all $5-\mathrm{HT}_{1 \mathrm{~A}}$ receptors in brain because those located postsynaptically in the hippocampus were found to exhibit the same characteristics in mutants as in wild-type animals.

Like that previously reported in rats (Rigdon and Wang, 1991; Le Poul et al., 1995), the increase in extracellular 5-HT concentrations within the DRN of brainstem slices exposed to SSRI (paroxetine, citalopram) was found to trigger a $5-\mathrm{HT}_{1 \mathrm{~A}}$ autoreceptor-mediated inhibition of DRN 5-HT cell firing in wild-type mice. This response offered a relevant model to further assess the lack of 5-HTT in the knock-out animals, and indeed, as expected, neither paroxetine nor citalopram were able to produce a concentration-dependent inhibition of DRN 5-HT cell firing in 5-HTT-/- mutants. These electrophysiological data further confirmed previous autoradiographic and biochemical results showing the complete absence of the SSRI molecular target, i.e., the 5-HTT, in the homozygous mutants (Bengel et al., 1998; Fabre et al., 2000). In contrast, experiments performed with tissues from heterozygous 5-HTT $+/-$ mice showed that paroxetine inhibited DRN 5-HT cell firing with the same potency in these mutants as in wild-type animals, although the density of 5-HT transporter binding sites was only half in the former compared with the latter group (Fabre et al., 2000). Interestingly, Bengel et al. (1998) reported that in vitro synaptosomal $\left[{ }^{3} \mathrm{H}\right] 5-\mathrm{HT}$ uptake was also unchanged in 5-HTT $+/-$ compared with wild-type animals. It can thus be hypothesized that adaptive changes in 5-HTT intrinsic activity very probably occur to compensate for the (partial) loss of 5-HTT protein in heterozygous 5-HTT+/- mutants.

One of the most interesting observations made in our studies is that spontaneous 5-HT neuron firing in brainstem slices was not altered in 5-HTT-/- mutants compared with wild-type mice. Because the electrophysiological activity of DRN 5-HT cells is 


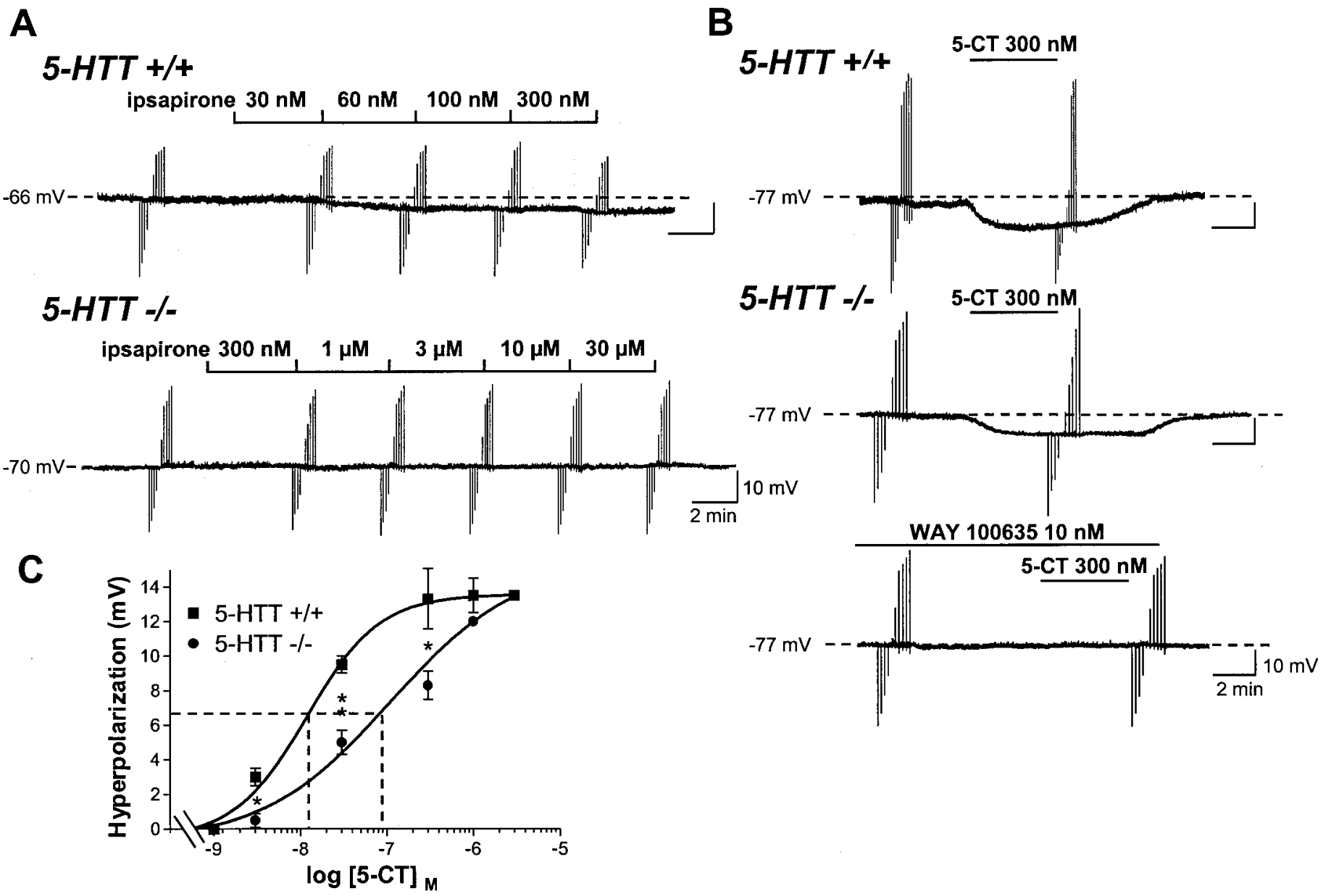

Figure 4. Differential effects of ipsapirone and 5-CT on intracellularly recorded DRN 5-HT neurons in 5-HTT knock-out and wild-type mice. A, Chart recordings of membrane potential of a DRN 5-HT neuron in a brainstem slice from a 5-HTT $+/+($ top $)$ versus a 5 -HTT $-/-($ bottom $)$ mouse. Each successive concentration of ipsapirone was applied for $4 \mathrm{~min}$. B, Same as in $A$, except that 5-CT (300 $\mathrm{nm}$ for $4 \mathrm{~min}$ ) was substituted for ipsapirone. Bottom recording shows the prevention by $10 \mathrm{~nm}$ WAY 100635 of 5-CT-induced hyperpolarization of the same cell as that corresponding to the middle recording. Downward and upward rapid deflections in $A$ and $B$ are electrotonic cell membrane responses to constant current steps $(-200$ to $+200 \mathrm{pA})$ injected through the recording electrode. Similar data were obtained in at least five cells in each group. $C$, Concentration-response curves of 5-CT-induced hyperpolarization of DRN 5-HT neurons in 5-HTT $+/+$ and 5-HTT $-/-$ mice. Each point is the mean \pm SEM of data obtained in three to five cells for each concentration of 5-CT. Dotted lines point to the $\mathrm{EC}_{50}$ values (abscissa). ${ }^{* *} p<0.01 ;{ }^{*} p<0.05$ compared with respective hyperpolarization in the 5-HTT $+/+$ group.

negatively controlled by extracellular 5 - $\mathrm{HT}$ acting at $5-\mathrm{HT}_{1 \mathrm{~A}}$ autoreceptors (Sprouse and Aghajanian, 1987; Haj-Dahmane et al., 1991), one would have expected that the lack of 5-HT reuptake produces some reduction in their firing rate because of the resulting increase in extracellular 5-HT levels in 5-HTT-/mice. Indeed, using in vivo microdialysis, marked increases (by at least sixfold) in extracellular 5-HT levels were found in the substantia nigra (Fabre et al., 2000) and the striatum (Andrews et al., 1998) of 5-HTT-/- compared with 5 -HTT $+/+$ mice. No data have yet been published concerning extracellular 5-HT concentrations within the DRN, but it can be reasonably assumed that they are also markedly enhanced in 5-HTT-/- mice, especially because the DRN contains a high density of 5-HT reuptake sites (Bengel et al., 1997; Rattray et al., 1999).

Because the most probable explanation for the maintenance of normal basal firing rate of DRN 5-HT cells in 5-HTT-/- mice is that $5-\mathrm{HT}_{1 \mathrm{~A}}$ autoreceptor-mediated inhibitory control is altered, we directly investigated the functional properties of DRN $5-\mathrm{HT}_{1 \mathrm{~A}}$ autoreceptors in these mutants. Like that previously observed in rats (Haj-Dahmane et al., 1991), bath application of ipsapirone induced a concentration-dependent inhibition of DRN
5-HT neuron firing in brainstem slices from mice of various strains, including 5-HTT $+/+$ animals. With respect to the inhibitory effect of ipsapirone, heterozygous 5-HTT $+/-$ mice did not significantly differ from wild-type mice (further supporting the idea that compensatory changes occurred in these mutants, see above), whereas homozygous 5-HTT-/- mutants were much less sensitive to the drug. Indeed ipsapirone potency was $\sim 55$-fold lower in the latter animals than in wild-type mice. Similar results were found using 5-CT, except that the potency of this agonist to inhibit DRN 5-HT neuron firing was decreased by only approximately sixfold in 5-HTT-/- compared with 5 -HTT $+/+$ animals. This difference between the two agonists was as expected from their respective efficacy at $5-\mathrm{HT}_{1 \mathrm{~A}}$ receptors, because it is well established (Kenakin, 1993) that reductions in receptor number and/or coupling, such as those affecting $5-\mathrm{HT}_{1 \mathrm{~A}}$ autoreceptors in 5-HTT-/- mice (Fabre et al., 2000), decrease to a greater extent the response to a low-efficacy (partial) agonist such as ipsapirone (Bockaert et al., 1987), than a high-efficacy (full) agonist such as 5-CT (Hoyer et al., 1994).

Interestingly, in addition to that of $5-\mathrm{HT}_{1 \mathrm{~A}}$ receptor agonists, the potency of baclofen, a GABA-B receptor agonist, to inhibit 
Figure 5. 5-CT-induced hyperpolarization of hippocampal CA1 pyramidal neurons of 5-HTT knock-out and wildtype mice. Prevention by WAY 100635 . $A$, Chart recordings of membrane potential of a CA1 pyramidal neuron intracellularly recorded in a hippocampal slice from a $5-\mathrm{HTT}+/+$ or a $5-\mathrm{HTT}-/-$ mouse. 5-CT (300 nM) was applied for 4 min. Full recovery of predrug value of membrane potential was observed $\sim 15$ min after cessation of 5-CT application. Downward and upward rapid deflections are electrotonic cell membrane responses to constant current steps $(-900$ to $+500 \mathrm{pA}$ ) injected through the recording electrode. $B$, Concentration-response curves of 5-CT-induced hyperpolarization of hippocampal CA1 neurons in 5 -HTT $+/+$ and 5-HTT- $/-$ mice. Each point is the mean \pm SEM of data obtained in four to seven cells for each concentration of 5-CT. Dotted lines point to the $\mathrm{EC}_{50}$ values (abscissa). $C$, Concentration-response curves of the antagonism by WAY 100635 of 5-CT (300 nM)-evoked hyperpolarization of hippocampal CA1 neurons in $5-\mathrm{HTT}+/+$ and 5-HTT-/- mice. Data are expressed as percentage of the response in the absence of WAY $100635(100 \%=$

-5.8 to $-6.7 \mathrm{mV}$; response range for $n=9$ individual cells in each group). Each point is the mean \pm SEM of data obtained in three or four cells for each concentration of WAY 100635. The dotted lines indicate the $\mathrm{IC}_{50}$ values of WAY 100635 (abscissa) against 5-CT-evoked hyperpolarization.
B

\section{$5-H T T+/+$}
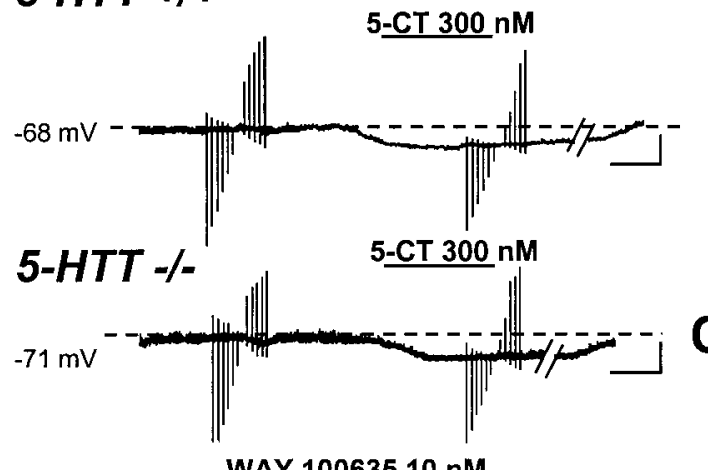

WAY $10063510 \mathrm{nM}$

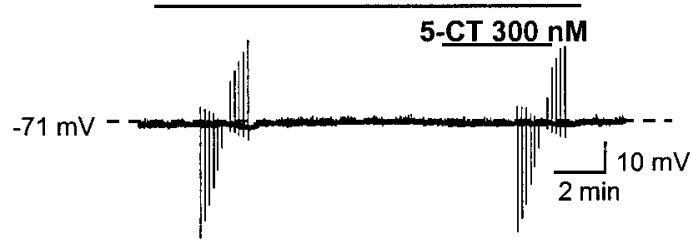

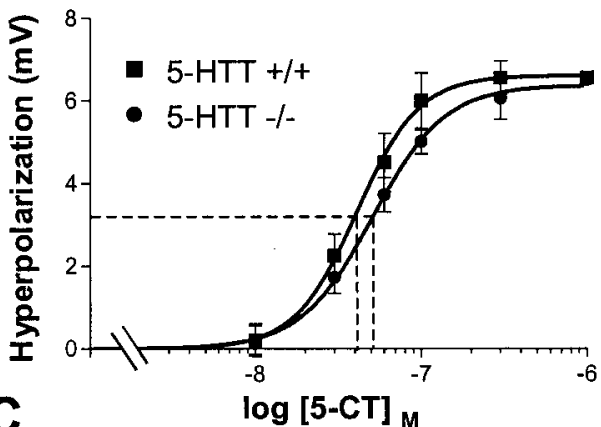

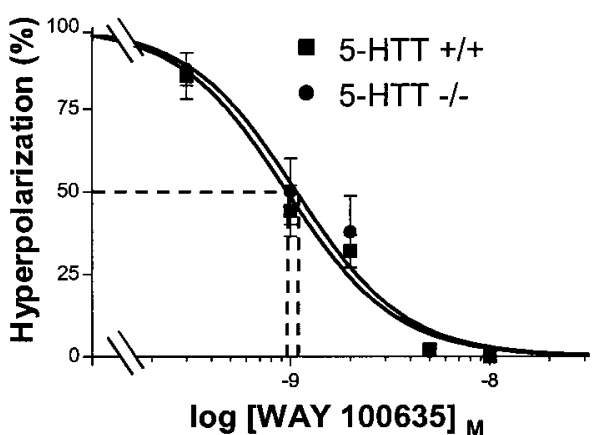

the discharge of DRN 5-HT neurons, was also found to be decreased in 5-HTT-/- versus 5-HTT $+/+$ mice (Mannoury La Cour et al., 2000). Because both 5-HT $\mathrm{HA}_{1 \mathrm{~A}}$ and GABA-B receptors share the same pool of G-proteins (Andrade et al., 1986), it can be inferred that possible alterations in this pool underlie their concomitant desensitization.

Further analyses of the $5-\mathrm{HT}_{1 \mathrm{~A}}$-mediated responses by intracellular recording of DRN 5-HT cells could not be performed with ipsapirone because this partial $5-\mathrm{HT}_{1 \mathrm{~A}}$ agonist lost its capacity to hyperpolarize the cell membrane in 5-HTT-/- mutants. This led us to use the full 5-HT $\mathrm{HT}_{1}$ agonist, 5-CT, whose effects on the membrane potential and $R_{\text {in }}$ also appeared to be completely prevented by WAY 100635 , as expected from their mediation through 5-HT $\mathrm{HA}_{1 \mathrm{~A}}$ receptors (Hamon, 1997). Indeed, 5-CT was still able to hyperpolarize the plasma membrane of DRN 5-HT neurons in 5-HTT-/- mice, but with a significantly lower potency than in wild-type animals. The differences between ipsapirone and 5-CT revealed by these intracellular recording experiments were also as expected from respective changes in the response to a partial and a full agonist (Bockaert et al., 1987; Hoyer et al., 1994) after alterations in their shared receptors (Kenakin, 1993) such as those observed in DRN 5-HT $1 \mathrm{~A}$ autoreceptors (Fabre et al., 2000).

Previous studies in rats have shown that chronic impairment of 5-HT reuptake by long-term SSRI treatment also induces a significant desensitization of DRN 5-HT $1 \mathrm{~A}$ autoreceptors (Chaput et al., 1986; Jolas et al., 1994; Kreiss and Lucki, 1995; Le Poul et al., 1995, 2000), thereby suggesting that similar mechanisms are responsible for this adaptive phenomenon in both SSRI-treated animals and 5-HTT knock-out mice. However, differences also exist between these two experimental models because in contrast to that found in 5-HTT-/- mice (Fabre et al., 2000), DRN $5-\mathrm{HT}_{1 \mathrm{~A}}$ autoreceptors are not downregulated in SSRI-treated rats (Le Poul et al., 1995, 2000). It has to be stressed, however, that 5-HTT is usually inhibited for only 2-3 weeks in pharmacological models, whereas it is completely inactivated for the whole life in knock-out animals, including at critical periods during development when 5-HT can play specific actions on brain maturation (Emerit et al., 1992; Lotto et al., 1999).

Another key feature of chronic SSRI treatments is the differential fate of hippocampal postsynaptic $5-\mathrm{HT}_{1 \mathrm{~A}}$ receptors versus DRN 5-HT $\mathrm{HA}_{1 \mathrm{~A}}$ autoreceptors in rats subjected to such treatments. Thus, in contrast to the latter receptors, those in the hippocampus do not desensitize after chronic SSRI administration (Haddjeri et al., 1998; Le Poul et al., 2000). To assess further the possible relevance of 5-HTT gene knock-out as a model of chronic 5-HTT blockade by SSRI, we investigated the functional characteristics of $5-\mathrm{HT}_{1 \mathrm{~A}}$ receptors on pyramidal cells in the CA1 area of the hippocampus in 5-HTT-/- mutants compared with wild-type mice. 5-CT, rather than ipsapirone, was used in these experiments because the partial agonist properties of the latter ligand produced only minor, not reliably measurable, hyperpolarization of CA1 pyramidal neurons (L. Lanfumey, unpublished observations). Like that observed in rats (Corradetti et al., 1998), 5-CT application onto mouse hippocampal slices produced both a hyperpolarization of the plasma membrane and a decreased $R_{\text {in }}$ of CA1 pyramidal cells that could be completely prevented by WAY 100635, demonstrating their mediation through $5-\mathrm{HT}_{1 \mathrm{~A}}$ receptors. Comparison of the potency of 5-CT to induce these effects in 5-HTT-/- versus 5 -HTT $+/+$ mice revealed no difference between the two groups, indicating that postsynaptic $5-\mathrm{HT}_{1 \mathrm{~A}}$ receptors were not desensitized in the knock-out animals. In line with these observations, Fabre et al. (2000) recently reported that $5-\mathrm{HT}_{1 \mathrm{~A}}$ receptor-evoked $\left[{ }^{35} \mathrm{~S}\right] \mathrm{GTP}-\gamma-\mathrm{S}$ specific binding was significantly decreased in the DRN but not the hippocampus in 5 -HTT-/- compared with wild-type mice. 
In conclusion, the present in vitro electrophysiological investigations demonstrated that somatodendritic $5-\mathrm{HT}_{1 \mathrm{~A}}$ autoreceptors in the DRN, but not postsynaptic $5-\mathrm{HT}_{1 \mathrm{~A}}$ receptors in the hippocampus, are desensitized in knock-out mice that lack 5-HT reuptake capacity. These adaptive changes closely resemble those induced by chronic SSRI treatment, indicating that 5 -HTT $-/-$ mice can be considered as a model to further investigate the molecular mechanisms underlying the differential regulation of 5-HT $\mathrm{HA}_{1 \mathrm{~A}}$ autoreceptors versus postsynaptic $5-\mathrm{HT}_{1 \mathrm{~A}}$ receptors (Hamon, 1997). The functional desensitization of DRN 5- $\mathrm{HT}_{1 \mathrm{~A}}$ autoreceptors probably explains why the basal firing rate of DRN 5-HT neurons remains at the same level as in wild-type animals despite marked increases in extracellular 5-HT levels in the mutants. Whether these differential changes in $5-\mathrm{HT}_{1 \mathrm{~A}}$ receptors in the DRN versus the hippocampus also account for the behavioral alterations in 5-HTT $-/-$ mice (Wichems et al., 2000) should deserve further investigations.

\section{REFERENCES}

Andrade R, Malenka RC, Nicoll RA (1986) A G protein couples serotonin and $\mathrm{GABA}_{\mathrm{B}}$ receptors to the same channels in hippocampus. Science 234:1261-1265.

Andrews AM, Wichems CH, Li Q, Heils A, Lesch KP, Murphy DL (1998) A microdialysis study of the effects of high $\mathrm{K}^{+}$and paroxetine on extracellular serotonin concentrations in serotonin transporter knock-out mice. Soc Neurosci Abstr 24:1112.

Asberg M, Thoren P, Träksman L (1976) Serotonin depression in a biochemical subgroup within the affective disorders. Life Sci 191:478-480.

Bengel D, Johren O, Andrews AM, Heils A, Mössner R, Sanvitto GL, Saavedra JM, Lesch KP, Murphy DL (1997) Cellular localization and expression of the serotonin transporter in mouse brain. Brain Res 778:338-345.

Bengel D, Murphy DL, Andrews AM, Wichems CH, Feltner D, Heils A, Mössner R, Westphal H, Lesch KP (1998) Altered brain serotonin homeostasis and locomotor insensitivity to 3,4methylenedioxymethamphetamine ("ecstasy") in serotonin transporterdeficient mice. Mol Pharmacol 53:649-655.

Bockaert J, Dumuis A, Bouhelal R, Sebben M, Cory RN (1987) Piperazine derivatives including the putative anxiolytic drugs, buspirone and ipsapirone, are agonists at $5-\mathrm{HT}_{1 \mathrm{~A}}$ receptors negatively coupled with adenylate cyclase in hippocampal neurons. Naunyn Schmiedebergs Arch Pharmacol 335:588-592.

Chang AS, Chang SM, Starnes DM, Schroeter S, Bauman AL, Blakely RD (1996) Cloning and expression of the mouse serotonin transporter. Mol Brain Res 43:185-192.

Chaput Y, de Montigny C, Blier P (1986) Effects of a selective 5-HT reuptake blocker, citalopram, on the sensitivity of 5-HT autoreceptors: electrophysiological studies in the rat brain. Naunyn Schmiedebergs Arch Pharmacol 333:342-348.

Corradetti R, Laaris N, Hanoun N, Laporte AM, Le Poul E, Hamon M, Lanfumey L (1998) Antagonist properties of (-)pindolol and WAY 100635 at somatodendritic and postsynaptic 5- $\mathrm{HT}_{1 \mathrm{~A}}$ receptors in the rat brain. Br J Pharmacol 123:449-462.

Cryan JF, Leonard BE (2000) 5- $\mathrm{HT}_{1 \mathrm{~A}}$ and beyond: The role of serotonin and its receptors in depression and the antidepressant response. Hum Psychopharmacol Clin Exp 15:113-135.

Emerit MB, Riad M, Hamon M (1992) Trophic effects of neurotransmitters during brain maturation. Biol Neonate 62:193-201.

Fabre V, Beaufour C, Evrard A, Rioux A, Hanoun N, Lesch KP, Murphy DL, Lanfumey L, Hamon M, Martres MP (2000) Altered expression and functions of serotonin $5-\mathrm{HT}_{1 \mathrm{~A}}$ and $5-\mathrm{HT}_{1 \mathrm{~B}}$ receptors in knock-out mice lacking the 5-HT transporter. Eur J Neurosci 12:2299-2310.

Graham D, Esnaud H, Habert E, Langer SZ (1989) A common binding site for tricyclic and nontricyclic 5-hydroxytryptamine uptake inhibitors at the substrate recognition site of the neuronal sodium-dependent 5-hydroxytryptamine transporter. Biochem Pharmacol 38:3819-3826.

Haddjeri N, Blier P, de Montigny C (1998) Long-term antidepressant treatments result in a tonic activation of forebrain $5-\mathrm{HT}_{1 \mathrm{~A}}$ receptors. J Neurosci 18:10150-10156.

Haj-Dahmane S, Hamon M, Lanfumey L (1991) $\mathrm{K}^{+}$Channel and 5 -hydroxytryptamine ${ }_{1 \mathrm{~A}}$ autoreceptor interactions in the rat dorsal raphe nucleus: an in vitro electrophysiological study. Neuroscience 41:495-505.

Hamon M (1997) The main features of central 5-HT $\mathrm{HT}_{14}$ receptors. In: Serotoninergic neurons and 5-HT receptors in the CNS. Handbook of experimental pharmacology, Vol 129, (Baumgarten HG, Göthert M, eds), pp 239-268. Berlin: Springer.

Hensler JG, Ferry RC, Labow DM, Kovachich GB, Frazer A (1994) Quantitative autoradiography of the serotonin transporter to assess the distribution of serotoninergic projections from the dorsal raphe nucleus. Synapse 17:1-15.

Hirst WD, Price GW, Rattray M, Wilkin GP (1998) Serotonin transporters in adult rat brain astrocytes revealed by $\left[{ }^{3} \mathrm{H}\right] 5$-HT uptake into glial plasmalemmal vesicles. Neurochem Int 33:11-22.

Hoyer D, Clarke DE, Fozard JR, Hartig PR, Martin GR, Mylecharane EJ, Saxena PR, Humphrey PPA (1994) VII. International Union of Pharmacology classification of receptors for 5-hydroxytryptamine (serotonin). Pharmacol Rev 46:157-203.

Jacobs BL, Azmitia EC (1992) Structure and function of the brain serotonin system. Physiol Rev 72:165-229.

Jolas T, Haj-Dahmane S, Kidd EJ, Langlois X, Lanfumey L, Fattaccini CM, Vantalon V, Laporte AM, Adrien J, Gozlan H, Hamon M (1994) Central pre- and postsynaptic $5-\mathrm{HT}_{1 \mathrm{~A}}$ receptors in rats treated chronically with a novel antidepressant, cericlamine. J Pharmacol Exp Ther 268:1432-1443.

Kenakin T (1993) Pharmacologic analysis of drug-receptor interaction, Ed 2. New York: Raven.

Kreiss DS, Lucki I (1995) Effects of acute and repeated administration of antidepressant drugs on extracellular levels of 5-hydroxytryptamine measured in vivo. J Pharmacol Exp Ther 274:866-876.

Le Poul E, Laaris N, Doucet E, Laporte AM, Hamon M, Lanfumey L (1995) Early desensitization of somato-dendritic 5- $\mathrm{HT}_{1 \mathrm{~A}}$ autoreceptors in rats treated with fluoxetine or paroxetine. Naunyn Schmiedebergs Arch Pharmacol 352:141-148.

Le Poul E, Boni C, Hanoun N, Laporte AM, Laaris N, Chauveau J, Hamon M, Lanfumey L (2000) Differential adaptation of brain $5-\mathrm{HT}_{1 \mathrm{~A}}$ and $5-\mathrm{HT}_{1 \mathrm{~B}}$ receptors and 5-HT transporter in rats treated chronically with fluoxetine. Neuropharmacology 39:110-122.

Lesch KP (1997) Molecular biology, pharmacology, and genetics of the serotonin transporter: psychobiological and clinical implications. In: Serotoninergic neurons and 5-HT receptors in the CNS. Handbook of experimental pharmacology, Vol 129 (Baumgarten HG, Göthert M, eds), pp 671-705. Berlin: Springer.

Li Q, Wichems C, Heils A, Van De Kar LD, Lesch KP, Murphy DL (1999) Reduction of 5-hydroxytryptamine (5-HT) $)_{1 \mathrm{~A}}$-mediated temperature and neuroendocrine responses and $5-\mathrm{HT}_{1 \mathrm{~A}}$ binding sites in 5-HT transporter knockout mice. J Pharmacol Exp Ther 291:999-1007.

Lotto B, Upton L, Price DJ, Gaspar P (1999) Serotonin receptor activation enhances neurite outgrowth of thalamic neurons in rodents. Neurosci Lett 269:87-90.

Mannoury La Cour C, Froger N, Lesch KP, Hamon M, Lanfumey L (2000) Common transduction mechanisms for $5-\mathrm{HT}_{1 \mathrm{~A}}$ and GABA-B receptors located on 5-HT neurons: further evidence in 5-HTT knockout mice. Eur J Neurosci [Suppl 11] 12:20.

Masson J, Sagné C, Hamon M, El Mestikawy S (1999) Neurotransmitter transporters in the central nervous system. Pharmacol Rev 51:439-464.

Pickel VM, Chan J (1999) Ultrastructural localization of the serotonin transporter in limbic and motor compartments of the nucleus accumbens. J Neurosci 19:7356-7366.

Rattray M, Michael G, Lee J, Wotherspoon G, Bendotti C, Priestley J (1999) Intraregional variation in expression of serotonin transporter messenger RNA by 5-hydroxytryptamine neurons. Neuroscience $88: 169-183$.

Rigdon GC, Wang CM (1991) Serotonin uptake blockers inhibit the firing of presumed serotoninergic dorsal raphe neurons in vitro. Drug Dev Res 22:135-140.

Rioux A, Fabre V, Lesch KP, Moessner R, Murphy DL, Lanfumey L, Hamon M, Martres MP (1999) Adaptive changes of serotonin 5-HT $\mathrm{H}_{2 \mathrm{~A}}$ receptors in mice lacking the serotonin transporter. Neurosci Lett 262:113-116.

Sanders-Bush E, Breeding M, Knoth K, Tsutsumi M (1989) Sertralineinduced desensitization of the serotonin $5-\mathrm{HT}_{2}$ receptor transmembrane signaling system. Psychopharmacology 99:64-69.

Sprouse JS, Aghajanian GK (1987) Electrophysiological responses of serotoninergic dorsal raphe neurons to $5-\mathrm{HT}_{1 \mathrm{~A}}$ and $5-\mathrm{HT}_{1 \mathrm{~B}}$ agonists. Synapse 1:3-9.

Sur C, Betz H, Schloss P (1996) Immunocytochemical detection of the serotonin transporter in rat brain. Neuroscience 73:217-231.

Tao-Cheng JH, Zhou FC (1999) Differential polarization of serotonin transporters in axons versus soma-dendrites: an immunogold electron microscopy study. Neuroscience 94:821-830.

Trulson ME, Frederickson CJ (1987) A comparison of the electrophysiological and pharmacological properties of serotonin-containing neurons in the nucleus raphe dorsalis, raphe medianus and raphe pallidus recorded from mouse brain slices in vitro: role of autoreceptors. Brain Res Bull 18:179-190.

VanderMaelen CP, Aghajanian GK (1983) Electrophysiological and pharmacological characterization of serotoninergic dorsal raphe neurons recorded extracellularly and intracellularly in rat brain slices. Brain Res 289:109-119.

Wichems C, Li Q, Andrews A, Lesch KP, Murphy DL (2000) Serotonin transporter knock-out mice show a spontaneous behavioural phenotype of increased "anxiety" and stress responses. Int J Neuropsychopharmacol [Suppl 1] 3:S47. 